\title{
Temperature effects on summer growth rates in the Antarctic scallop, Adamussium colbecki
}

Received: 18 August 2004/ Revised: 29 December 2004/ Accepted: 3 January 2005 / Published online: 17 February 2005 (C) Springer-Verlag 2005

\begin{abstract}
Annual growth rates of Antarctic marine organisms are low compared to their relatives from warmer waters. Previous studies hypothesise that high food availability during austral spring-summer may enable Antarctic invertebrates to attain comparatively high short-term growth rates despite the low temperature. Neither a temperature-growth experiment with juvenile Adamussium colbecki (Smith 1902) nor the comparison of A. colbecki summer growth rates with an empirical scallop specific growth-to-temperature relationship could confirm this hypothesis. Hence, summer growth rates of young, immature $A$. colbecki are strongly affected by temperature, i.e. no "uncoupling" from temperature.
\end{abstract}

Keywords Adamussium colbecki A Antarctic scallop · Growth $\cdot$ Growth rate $\cdot$ Temperature

\section{Introduction}

Antarctic marine metazoans are characterised by low overall metabolic rates, low levels of activity, low turnover ratios and slow individual growth (Brey and Clarke

O. Heilmayer · U. Jacob · T. Brey

Alfred Wegener Institute for Polar and Marine Research, P.O. Box 120161, 27515 Bremerhaven, Germany

O. Heilmayer $(\square)$

Department of Biological Sciences, Florida Atlantic University, 777 Glades Road, SC 214, Boca Raton, Fl-33431, USA

E-mail: oheilmay@fau.edu

Tel.: + 1-561-297-0383

Fax: + 1-561-297-2749

C. Honnen

Gymnasium Wesermünde, Humboldtstrasse 12-14, 27580 Bremerhaven, Germany

M. Chiantore $\cdot$ R. Cattaneo-Vietti

DIP.TE.RIS Dipartimento per lo Studio del

Territorio e delle sue Risorse, Università di Genova,

Viale Benedetto XV, 5-16132 Genova, Italy
1993; Arntz et al. 1994). Historically this has been explained as an unavoidable consequence of lowered temperature on the physiology of these organisms. More recently it has been proposed that seasonal resource limitation rather than temperature represents the restricting factor for polar marine environments (Arntz et al. 1994; Clarke 1998). In Polar regions, productivity and consequently growth is usually confined to the short summer season (e.g. Nolan and Clarke 1993; Barnes 1995). There is some evidence that during periods of high food supply (spring-summer) growth rates of Antarctic invertebrates may be as high as in their temperate relatives (e.g. Clarke 1988; Brey and Hain 1992; Ahn et al. 2003). Evidence for the role of seasonality comes from bivalves, where latitudinal variation in annual shell growth rate is strongly correlated with the number of days in the year on which feeding was possible (e.g. Chauvaud and Strand 1999), as well as from the Antarctic invertebrates, such as the bryozoan $\mathrm{Cel}$ larinella (Barnes 1995) and the sea urchin Sterechinus neumayeri (Brockington et al. 2001).

Evidence suggests that the capacity for growth (i.e. maximum growth potential) within taxonomically closely related species may vary inversely with the length of the growing season across a latitudinal gradient either to compensate in part (Levinton and Monahan 1983) or even in full (MacDonald and Thompson 1988) for environmental effects (countergradient variation, e.g. Conover and Schultz 1995; Arendt 1997). However, most growth comparisons across latitudes are based largely on the comparison of annual rates. Hence, it may be important to measure growth rates on time scales that are appropriate to the individual in nature (i.e. by explicitly comparing maximum growth rates). Thus, the short growing season may constrain individual growth more than the permanently low temperature (Clarke 1998; Peck 2002). Our study investigates whether this general pattern may be true for the Antarctic scallop, Adamussium colbecki (Smith 1902), a key species in Antarctic shallow-water communities (Cattaneo-Vietti et al. 1997; 
Chiantore et al. 2000). Based on a comparison of our own and published experimental data, we ask two questions: (1) Is the growth rate-to-temperature relationship of A. colbecki in a "normal' range compared to lower latitude scallop species and (2) is the summer growth rate of $A$. colbecki above the temperature-to-growth rate range found in temperate and warm water scallops?

\section{Material and methods}

Adamussium colbecki summer growth experiment

In summer 1999/2000, 28 juvenile $A$. colbeck $i$ [size range: $10.2-16.9 \mathrm{~mm}$ shell height: $4.7-33.9 \mathrm{mg}$ shell free dry mass (SFDM)] were collected near the Italian Antarctic station 'Terra Nova Bay' (7441.9'S, $\left.164^{\circ} 07.5^{\prime} \mathrm{E}\right)$ from $60 \mathrm{~m}$ to $80 \mathrm{~m}$ water depth. Animals were incubated for $12 \mathrm{~h}$ in slightly aerated filtered seawater with calcein $(2,4-$ bis-[N,N'-di(carbomethyl)-aminomethyl]-fluorescein: Sigma C0875) (1 g calcein $1^{-1}$, pH 8; modified after Dahm 1996). Calcein was used for setting artificial growth marks in calcium carbonate skeletons as it is incorporated into the growing calcium carbonate structure and fluorescences under UV light. It has been used previously in various taxa, including fishes (e.g. Mohler 1997), echinoderms (e.g. Dahm 1996) and molluscs (e.g. Kaehler and McQuaid 1999; Moran 2000; Clarke et al. 2004). After incubation, animals were randomly divided into three groups maintained under natural light and food regime: (1) Group A1 $(N=10)$ and Group A2 $(N=12)$ at actual environmental temperature $\left(0 \pm 0.5^{\circ} \mathrm{C}\right)$ for a period of one, respectively, two weeks, and (2) Group B $(N=6)$ for one week at $3 \pm 0.5^{\circ} \mathrm{C}$. Total growth increment (calcein mark to shell edge) was measured under UV light with a Wild Microscope M6, equipped with a microscale and transformed to daily shell growth rate.

Empirical data on scallop growth

A general relation between temperature and short-term growth rates in scallops was based on growth data from the literature, which (1) referred to juvenile, premature individuals and (2) were measured during the main growth period of the species.

\section{Hypothesis testing}

(a) Is temperature sensitivity of the summer shell growth rate of $A$. colbecki in the 'normal' range observed in lower latitude scallops?

If growth of $A$. colbecki is less temperature sensitive, than an additional increase in temperature on top of enhanced food availability, should cause a comparatively low increase in growth rate. To test whether a temperature increase of $3^{\circ} \mathrm{C}$ increased the summer growth rate of juvenile $A$. colbecki less $\left(H_{0}\right)$ or as strongly as (or stronger than) $\left(H_{A}\right)$ predicted by the overall empirical relation between temperature and growth rate in pectinids, we compared the $Q_{10}$ values of $A$. colbecki growth with corresponding $Q_{10}$ values from published comparable intraspecific growth studies.

(b) Is the summer growth rate of $A$. colbecki above the temperature-to-growth rate range found in temperate and warm water scallops?

If summer growth rates of $A$. colbecki are "less" limited by temperature, than they should substantially deviate from the temperature-to-growth rate range found in scallops living in temperate and warm waters. This would indicate specific temperature adaptations in the Antarctic scallop. An ANCOVA (growth rate as dependent variable, Antarctic $\leftrightarrow$ non-Antarctic as factor and $1 / T$ as a covariate) was applied to our collection of scallop growth data to test whether summer growth rates of $A$. colbecki are within the range $\left(H_{0}\right)$ or higher $\left(H_{A}\right)$ than predicted from the relation between temperature and (summer) growth rates.

\section{Results and discussion}

Adamussium colbecki summer growth rates

Individual daily growth rates in calcein marked $A$. colbecki ranged from $10.7 \mu \mathrm{m} /$ day to $84 \mu \mathrm{m} /$ day (Fig. 1). Mean daily shell growth rates at $0^{\circ} \mathrm{C}, 19.75 \pm 6.26 \mu \mathrm{m} /$ day in Group A1 and 19.28 $\pm 8.10 \mu \mathrm{m}$ /day in Group A2, were indiscriminable but were significantly $(\alpha=0.05)$ lower than growth rates at $3^{\circ} \mathrm{C}, 71.25 \pm 14.14 \mu \mathrm{m} /$ day in Group B (one-way ANOVA with Student-Newman post hoc test). Daily summer growth rates of $A$. colbecki are clearly higher than published data for other Antarctic bivalves (e.g. Yoldia eightsi, Peck et al. 2000), emphasizing that $A$. colbecki is a fast growing species

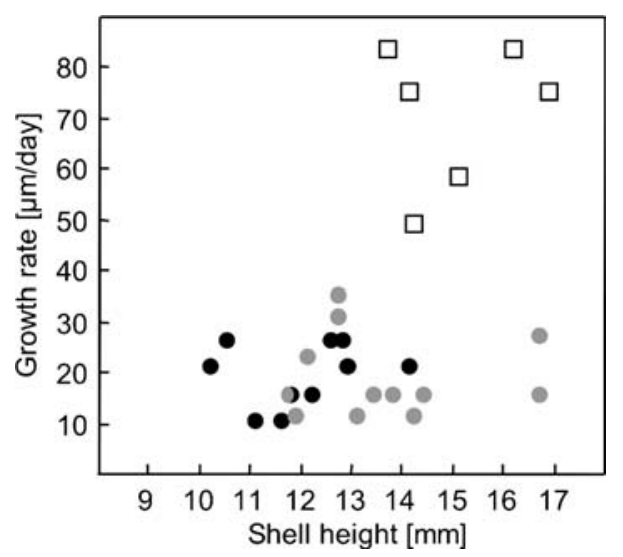

Fig. 1 Adamussium colbecki. Relationship between shell height and daily growth rate within juvenile Antarctic scallops maintained at two different temperatures. Growth estimates were obtained by increment determination after one, respectively, two weeks (circles: Group $\mathrm{A} 1,0^{\circ} \mathrm{C}$, one week; dots: Group A2, $0^{\circ} \mathrm{C}$, two weeks; squares: Group $\mathrm{B}, 3^{\circ} \mathrm{C}$, one week) 
(Heilmayer et al. 2003). Growth rates at $0^{\circ} \mathrm{C}$ are in the range of data for adult individuals from Mc Murdo Sound (Berkman 1990). Hence, in contrast to annual growth rates (Heilmayer et al. 2003), there is no evidence for age dependence in short-term growth rate as observed for other mollusc species (i.e. Sukhotin et al. 2002). This may be due to (1) different environmental conditions of both study sites or (2) a compensatory growth increase after a period of inhibition as observed frequently in marine poikilotherms (e.g. Schultz et al. 2002).

Temperature sensitivity of $A$. colbecki summer growth rates

The threefold increase from $0^{\circ} \mathrm{C}$ to $3^{\circ} \mathrm{C}$ corresponds to a $Q_{10}$ value of 71.28 , which is clearly the highest $Q_{10}$ value found among temperate and warm water scallops, which range from 2.68 (overall comparison, Fig. 2) to 3.19 (Placopecten magellanicus). These findings indicate that summer growth rates of $A$. colbecki are not less temperature sensitive than in other pectinids. On the contrary, the high $Q_{10}$ values at low temperatures may be indicative of a change in the properties of the underlying biochemical systems, such that the energy barriers to the process questioned are increased (Clarke 1988, 2003). High $Q_{10}$ values (i.e. being above physiological normal values) have been reported for various complex processes of Antarctic invertebrates, such as growth (Clarke 1988) or embryonal development time (Yoshida et al. 2004). The mechanism, however, underlying the high increase of $Q_{10}$ values is still subject of ongoing discussions.

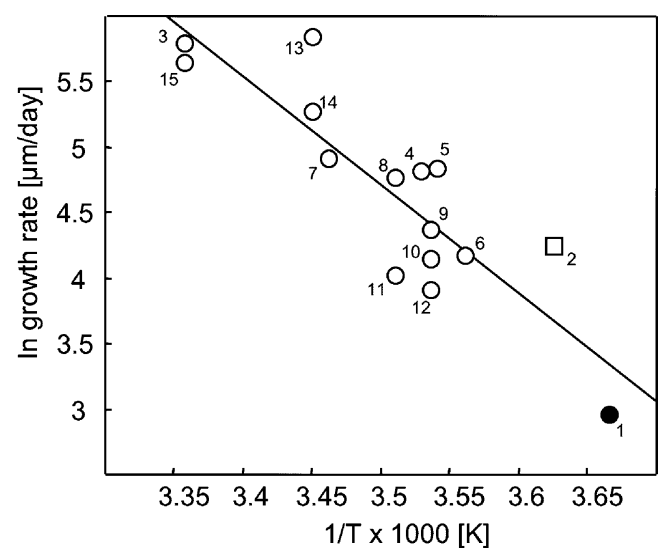

Fig. 2 Mean daily shell growth ( $\mu \mathrm{m} /$ day) for six scallop species from different latitudes. Shown are values measured at main growth periods in juvenile/premature scallops: 1-2: Adamussium colbecki $\left(1\right.$ this study $0^{\circ} \mathrm{C}, 2$ this study, $\left.+3^{\circ} \mathrm{C}\right) ; 3$ : Argopecten circularis (Ruiz-Verdugo and Cáceres-Martinez 1991); 4-5: Chlamys islandica(Thorarinsdôttir 1994); 6: Mizuhcopecten yessoensis (Maru 1985); 7-12: Placopecten magllanicus (Dadswell 1989; Chandler et al. 1989; Dadswell and Parsons 1991; Thouzeau et al. 1991; Parsons et al. 1993); 13-14: Pecten maximus (Chauvaud et al. 1998; 13 1-year-old, 14 2-years-old); 15: Pecten vogdesi (RuizVerdugo and Cáceres-Martinez 1991). Arrhenius plot, with fitted least-squares regression line (only populations 3 to 15): ln shell growth $(\mu \mathrm{m} /$ day $)=33.65-8.268 \quad 1,000 / T \quad\left(N=13, \quad r^{2}=0.693\right.$, $P<0.001)$
Specific temperature adaptations in $A$. colbecki

Daily growth rates of scallops are significantly and positively related to temperature (Fig. 2), as indicated by the Arrhenius equation: In shell growth $(\mu \mathrm{m} /$ day $)=$ $33.65-8.2681,000 / T \quad\left(N=13, r^{2}=0.693, \quad P<0.001\right)$. There is no significant regional effect on growth rate detectable (ANCOVA: growth rate as dependent variable, Antarctic $\leftrightarrow$ non-Antarctic as factor and $1 / T$ as a covariate) $(F=0.0061, P>0.5)$. Thus, growth rates of $A$. colbecki do not differ from growth rates of other scallop species if the overall temperature dependence has been accounted for. Our results confirm previous results based on a latitudinal comparison of annual rates (e.g. Harrington 1987; Heilmayer et al. 2003, 2004). In contrast, an increased growth rate working against the limiting effects of cold temperature are widespread in fishes (Conover and Schultz 1995) and marine invertebrates, including copepods (Lonsdale and Levinton 1985), polychaetes (Levinton and Monahan 1983) and gastropods (Parsons 1997) (countergradient growth).

The observed growth pattern of Antarctic scallops raises a number of issues concerning trade-offs between the capacity for growth and other physiological or lifehistory traits. Antarctic herbivores may employed a variety of feeding and growth strategies to cope with extreme food and environmental seasonality: (1) efficient feeding, feeding throughout the whole year (Barnes 1995; Peck et al. 2000) (2) and brief period of intensive feeding and growth during austral summer followed by winter starvation (Clarke 1988; Barnes 1995). Further field studies, especially under winter conditions, are necessary to determine the factors underlying the growth patterns in A. colbecki.

\section{Conclusions}

Growth rates of $A$. colbecki are neither less temperature sensitive, than in temperate and warm water pectinids, nor do they deviate from the growth rate-to-temperature relation common to all scallop species (no evidence for countergradient variation). There are no unique growth characteristics of Antarctic scallops, once the effects of temperature have been eliminated (i.e. no "uncoupling" from temperature). Thus, our observations indicate that temperature is a major constraint of summer growth rates in $A$. colbecki .

Acknowledgements We thank the members of the Italian Antarctic Research station 'Terra Nova Bay', especially the 'Malippo'-Crew and the divers for sampling of animals. Daniela Storch (AWI) helped during several aspects of the study. This research has been carried out - thanks to the support of the Italian National Program for Antarctic Research (PNRA) and the Alfred Wegener Institute for Polar and Marine Research (AWI). The manuscript benefited greatly from the comments of Andrew Clarke (British Antarctic Survey), Alex Sukhotin (White Sea Biological Station) and an anonymous reviewer. 


\section{Appendix}

Table a Short-term growths rates in different scallops, which refer to juvenile, premature individuals and are measured during the main growth period of the species

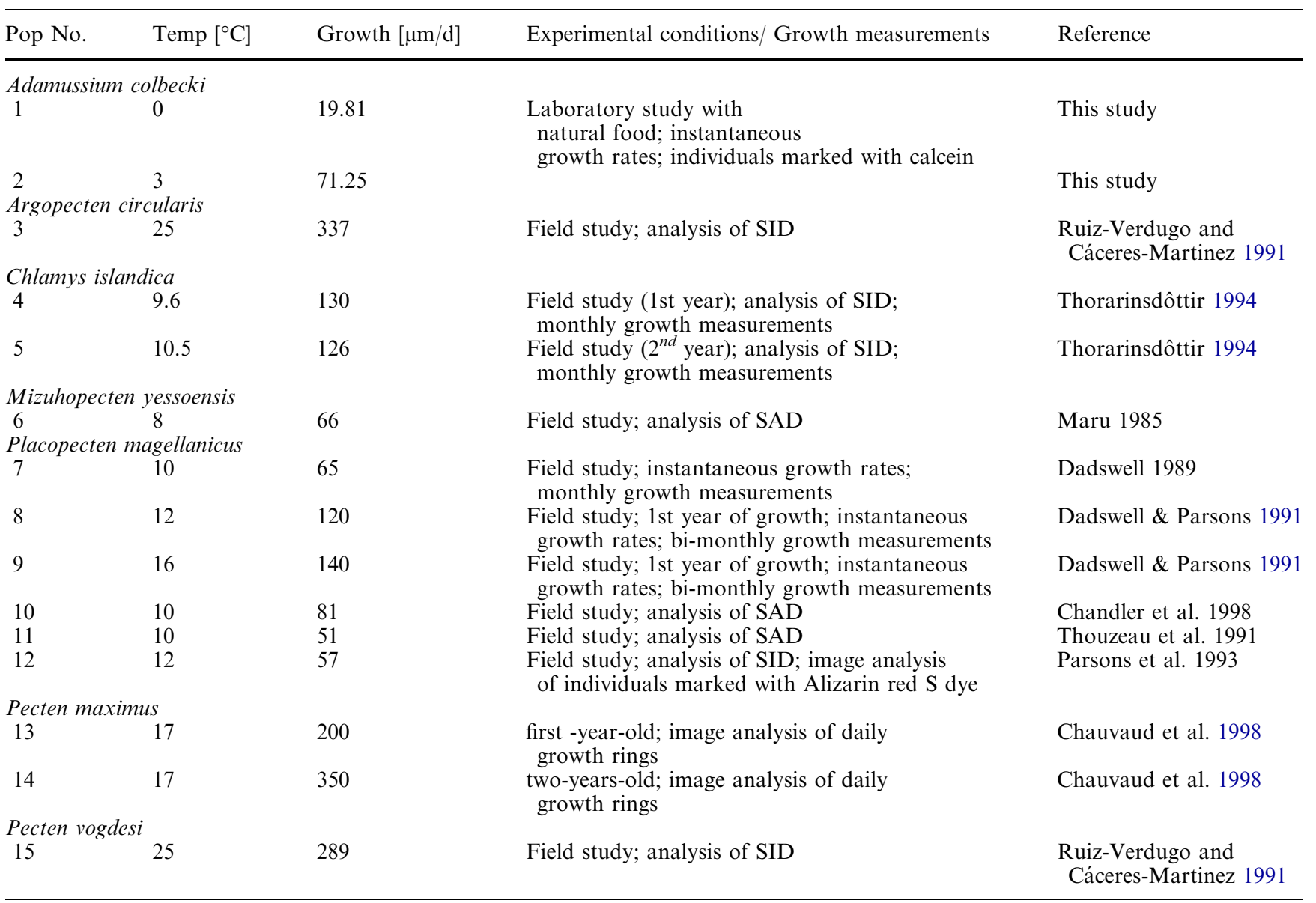

Study conditions are summarized as far as available

$S I D$ Size-increment-data; $S A D$ Size-at-age data

\section{References}

Ahn IY, Surh J, Park YG, Kwon H, Choi KS, Kang SH, Choi HJ, Kim KW, Chung H (2003) Growth and seasonal energetics of the Antarctic bivalve Laternula elliptica from King George Island, Antarctica. Mar Ecol Prog Ser 257:99110

Arendt J (1997) Adaptive intrinsic growth rates: an integration across taxa. Q Rev Biol 72:149-177

Arntz WE, Brey T, Gallardo VA (1994) Antarctic zoobenthos. Oceanogr Mar Biol Ann Rev 32:241-304

Barnes DKA (1995) Seasonal and annual growth in erect species of Antarctic bryozoans. J Exp Mar Biol Ecol 188:181-198

Berkman PA (1990) The population biology of the Antarctic scallop, Adamussium colbecki (Smith 1902) at New Harbor, Ross Sea. In: Kerry KR, Hempel G (eds) Antarctic ecosystems: ecological change and conservation. Springer, Berlin Heidelberg, New York, pp 281-288

Brey T, Clarke A (1993) Population dynamics of marine benthic invertebrates in Antarctic and subantarctic environments: are there unique adaptations. Ant Sci 5:253-266

Brey T, Hain S (1992) Growth, reproduction and production of Lissarca notorcadensis (Bivalvia: Philobryidae) in the Weddell Sea, Antarctica. Mar Ecol Prog Ser 82:219-226
Brockington S, Clarke A, Chapman ALG (2001) Seasonality of feeding and nutritional status during the austral winter in the Antarctic sea urchin Sterechinus neumayeri. Mar Biol 139:127138

Cattaneo-Vietti R, Chiantore M, Albertelli G (1997) The population structure and ecology of the Antarctic scallop Adamussium colbecki (Smith, 1902) at Terra Nova Bay (Ross Sea, Antarctica). Sci Mar 61 (Suppl 2):15-24

Chandler RA, Parsons GJ, Dadswell MJ (1989) Upper and northern Bay of Fundy scallop surveys, 1986-1987. Can Tech Rep Fish Aquat Sci 1665:37

Chauvaud L, Strand O (1999) Growth traits in three populations of Pecten maximus. Book of Abstracts: 12th international pectinid workshop, pp 166-167

Chauvaud L, Thouzeau G, Paulet YM (1998) Effects of environmental factors on the daily growth rate of Pecten maximus juveniles in the Bay of Brest (France). J Exp Mar Biol Ecol 227:83-111

Chiantore M, Cattaneo-Vietti R, Albertelli G (2000) The population structure and ecology of the Antarctic Scallop Adamussium colbecki in Terra Nova Bay. In: Faranda FM, Guglielmo L, Ianora A (eds) Ross Sea Ecology: Italiantartide Expeditions (19871995). Springer, Berlin Heidelberg New York, pp 563-573

Clarke A (1988) Seasonality in the antarctic marine environment. Comp Biochem Physiol 90B:461-473 
Clarke A (1998) Temperature and energetics: an introduction to cold ocean physiology. In: Pörtner HO, Playle R (eds) Cold ocean physiology. University Press, Cambridge, pp 3-30

Clarke A (2003) Costs and consequences of evolutionary temperature adaptation. Trends Ecol Evol 18:573-581

Clarke A, Prothero-Thomas E, Beaumont JC, Chapman AL, Brey $T$ (2004) Growth in the limpet Nacella concinna from contrasting sites in Antarctica. Polar Biol 28:62-71

Conover DG, Schultz ET (1995) Phenotypic similarity and the evolutionary significance of countergradient variation. Trends Ecol Evol 10:248-252

Dadswell MJ (1989) Potential for giant scallop (Placopecten magellanicus) aquaculture in Atlantic Canada. Aquacult Assoc Can Bull 89:19-22

Dadswell MJ, Parsons GJ (1991) Potential for aquaculture of sea scallop, Placopecten magellanicus (Gmelin, 1791) in the Canadian Maritimes using naturally produced spat. In: Shumway SE, Sandifer PA (eds) An international compendium of scallop biology and culture World aquaculture workshops. The World Aquaculture Society, Baton Rouge LA, pp 300-307

Dahm C (1996) Ökologie und Populationsdynamik antarktischer Ophiuroiden (Echinodermata). Ber Polarforsch 194:1-289

Harrington RJ (1987) Skeletal growth histories of Protothaca staminea (Conrad) and Protothaca grata (Say) throughout their geographic ranges, northeastern Pacific. Veliger 30:148158

Heilmayer O, Brey T, Chiantore M, Cattaneo-Vietti R, Arntz WE (2003) Age and productivity of the Antarctic scallop, Adamussium colbecki, in Terra Nova Bay (Ross Sea, Antarctica). J Exp Mar Biol Ecol 288:239-256

Heilmayer O, Brey T, Pörtner HO (2004) Growth efficiency and temperature in scallops: a comparative analysis of species adapted to different temperatures. Funct Ecol 18:641-647

Kaehler S, McQuaid CD (1999) Use of the fluorochrome calcein as an in situ growth marker in the brown mussel Perna perna. Mar Biol 133:455-460

Levinton JS, Monahan RK (1983) The latitudinal compensation hypothesis: growth data and a model of latitudinal growth differentiation based upon energy budgets. II. Intraspecific comparisons between subspecies of Ophryotrocha puerilis (Polychaeta: Dorvilleidae). Biol Bull 165:699-707

Lonsdale DJ, Levinton JS (1985) Latitudinal differentiation in copepod growth: an adaptation to temperature. Ecology 66:1397-1407

MacDonald BA, Thompson RJ (1988) Intraspecific variation in growth and reproduction in latitudinally differentiated populations of the giant scallop Placopecten magellanicus (Gmelin). Biol Bull 175:361-371
Maru K (1985) Ecological studies on the seed production of scallop, Patinopecten yessoensis (Jay). Sci Rep Hokk Fish Exp Stud 27:1-55

Mohler JW (1997) Immersion of larval Atlantic salmon in calcein solutions to induce a non-lethally detectable mark. N Am J Fish Mgmt 17:751-756

Moran AL (2000) Calcein as a marker in experimental studies newly-hatched gastropods. Mar Biol 137:893-898

Nolan CP, Clarke A (1993) Growth in the bivalve Yoldia eightsi at Signy Island, Antarctica, determined from internal shell increments and calcium-45 incorporation. Mar Biol 117:243-250

Parsons KE (1997) Contrasting patterns of heritable geographic variation in shell morphology and growth potential in the marine gastropod Bembicium vittatum: evidence from field experiments. Evolution 51:784-796

Parsons GJ, Robinson SMC, Roff JC, Dadswell MJ (1993) Daily growth rates as indicated by valve ridges in postlarval giant scallop (Placopecten magellanicus) (Bivalvia: Pectinidae). Can J Fish Aquat Sci 50:456-464

Peck LS (2002) Ecophysiology of Antarctic marine ectotherms: limits to life. Polar Biol 25:31-40

Peck LS, Colman JG, Murray AWA (2000) Growth and tissue mass cycles in the infaunal bivalve Yoldia eightsi at Signy Island, Antarctica. Polar Biol 23:420-428

Ruiz-Verdugo CA, Cáceres-Martinez C (1991) Experimental spat collection of scallops Argopecten circularis (Sowerby, 1835), and Pecten vogdesi (Arnold, 1906) on a filament substrate in Falsa Bay, B.C.S. Mexico. In: Shumway SE, Sandifer PA (eds) An international compendium of scallop biology and culture World aquaculture workshops. The World of Aquaculture Society, Baton Rouge, pp 21-27

Schultz ET, Lankford TE, Conover DO (2002) The covariance of routine and compensatory juvenile growth rates over a seasonality gradient in a coastal fish. Oecologia 133:501-509

Sukhotin AA, Abele D, Pörtner HO (2002) Growth, metabolism and lipid peroxidation in Mytilus edulis: age and size effects. Mar Ecol Prog Ser 226:223-234

Thorarinsdôttir GG (1994) The Iceland scallop, Chlamys islandica (O.F. Müller), in Breidafjordur, west Iceland. III. Growth in suspended culture. Aquacult 120:295-303

Thouzeau G, Robert G, Smith SJ (1991) Spatial variability in distribution and growth of juvenile and adult sea scallop Placopecten magellanicus (Gmelin) on eastern Georges Bank (Northwest Atlantic). Mar Ecol Prog Ser 74:205-218

Yoshida T, Toda T, Hirano Y, Matsuda T, Kawaguchi S (2004) Effect of temperature on embryo development time and hatching success of the Antarctic krill Euphausia superba dana in the laboratory. Mar Fresh Behav Physiol 37:137-145 